\title{
FEATURES OF MEDICAL TERMINOLOGY TEACHING IN ENGLISH LESSONS
}

\author{
CAbidova M., ORCID: 0000-0002-3168-3524, Tashkent State Dental Institute, \\ Tashkent,Uzbekistan, sultanova_dilfuz@mail.ru \\ CGuzacheva N., ORCID: 0000-0003-1461-0718, Tashkent Pediatric Medical Institute, \\ Tashkent, Uzbekistan

\section{ОСОБЕННОСТИ ПРЕПОДАВАНИЯ МЕДИЦИНСКОЙ ТЕРМИНОЛОГИИ НА ЗАНЯТИЯХ ПО АНГЛИЙСКОМУ ЯЗЫКУ}

\author{
(САбидова М. И., ORCID: 0000-0002-3168-3524, Ташкентский государственный \\ стоматологический институт, г.Ташкент, Узбекистан, sultanova_dilfuz@mail.ru \\ СГузачева Н. И., ОRCID: 0000-0003-1461-0718, Ташкентский педиатрический \\ медицинский институт, г. Ташкент, Узбекистан
}

Abstract. The purpose of this study is to consider issues related to the teaching of English for medical purposes in modern higher education. As you know, English is an integral part of a successful professional career in medicine. In addition, various international projects in the field of medicine are becoming more widespread, participation in which is also an important part of professional development for medical workers. In this article, the authors substantiates the importance of reviewing certain aspects of teaching English to medical students and offer their concept of an English course for medical purposes.

Аннотация. Целью данного исследования является рассмотрение вопросов, связанных с преподаванием английского языка для медицинских целей в современной высшей школе. Как известно, английский язык является неотъемлемой составляющей успешной профессиональной карьеры в сфере медицины. Кроме того, все большее распространение получают различные международные проекты в сфере медицины, участие в которых также является важной частью профессионального становления для медицинских работников. В настоящей статье авторs обосновывают необходимость пересмотра определенных аспектов в преподавании английского языка студентам-медикам и предлагает свою концепцию курса английского языка для медицинских целей.

Keywords: English for special purposes, Medical English, medical terminology, professional communication.

Ключевые слова: английский язык для специальных целей, медицинский английский язык, медицинская терминология, профессиональная коммуникация.

Due to the Globalization of the processes of professional communication, English language is becoming more widespread and significant in almost all areas of special knowledge. Communication skills in English in the field of information technology and medicine are required nowadays. Currently, there is a significant growth of the number of English-language scientific publications on medical topics, in addition, $80 \%$ of scientific journals indexed in the international Scopus database are also published in English. English is also the official language of most international conferences. In addition, more and more medical specialists of the Republic of 
Uzbekistan are collaborating with professional teams and medical institutions from Englishspeaking countries, and medical internships are now becoming more accessible for medical students, which also requires communication skills in English and confident knowledge of medical terminology [1].

Taking into consideration all of the above requirements and challenges that reality throws at us, the need to rethink some aspects of teaching English to medical students is becoming more acute. This is explained by the fact that only the full development of competencies that ensure highquality communication between future doctors with their foreign colleagues in various academic and professional situations is a key factor to the productivity and success of the work of our country medical workers

Consequently, there are some difficulties in working with students, who study a foreign language for special purposes. Firstly, it is the fact that the time for preparation can be seriously limited. Secondly, specific requests and needs of students create additional difficulties for the teacher, which are associated with the actualization of English language in the field of highly specialized professional communication.

This situation often requires from the teacher to develop creative materials, which will be up to the academic needs of students. The solution of such problems are caused by the specificity of the professional field and the individualization of approaches to education is possible by attracting various authentic medical documents in English - newsletters for patients, medical questionnaires, video materials and brochures in English that are distributed in medical institutions in Englishspeaking countries with the purpose of educational work among population, in English-language medical sites and television shows, which allow people to have a healthy lifestyle. All of these resources are extremely valuable for developing this type of course.

We consider the issues of studying medical terminology in the lessons of the English language with a foreign audience. Medical terminology is a macroterminosystem consisting of subsystems, each of which has its own characteristics. This phenomenon must be considered in creating a system of tasks and exercises for teaching English as a foreign language to medical students.

We analyze the methods of semanticization of medical terms, describe the principles of planning the program of the English language course for medical students, and suggest methods for developing the skills of dialogical speech at different stages of the lesson. We review and group the most productive methods of language aspects teaching, their use in writing and speaking; we present the criteria for the selection of educational material aimed at the formation and improvement of phonetic, lexical, grammatical, morphological and syntactic skills [2].

Listening is a mandatory component of any English as a foreign language lesson. We present the possible topics and options for working with anatomical and clinical terminology. We conclude that teaching the language of the specialty for medical students should be diverse, multidisciplinary and include work to realize three main aims: teaching, developing and educational.

In professional context, in the methodology of teaching English language for special purposes to medical students, it is important to know and understand all the features of medical terminology.

Work with professional vocabulary goes through the following stages:

1) presentation of new vocabulary;

2) formation of lexical skills;

3) the organization of conditions to review new vocabulary.

Scientific and technical literature is characterized by the use of terminological units. Hundreds of thousands of words and word-combinations belong to the terminological systems of science, technology, trade, law, sports. These linguistic units are not used or even understood by people outside the particular specialty. Every field of science or activity has its specialized vocabulary. 
There is a special medical vocabulary, and similarly special terminologies for chemistry, physics, power engineering, economics, building construction, aviation, and many others [3].

Teaching vocabulary is one of the priority tasks of teaching English for special purposes. The relevance of teaching a foreign language to a specialty is determined by the need to use this language in professional activities and mastering communication skills on professional topics, as well as reading, abstracting and translation of specialized literature.

Terminology, as traditionally understood, is a word or a word-combination which is specifically used within a particular branch of science, technology, trade, law, sports or the arts to convey a concept peculiar to this particular field.

As it is known, teaching terminological vocabulary as part of a foreign language course for special purposes is one of the most important components of the task of forming a professionallyoriented communicative competence of non-philological students. Terminology is a means of providing information and mutual understanding of communicators in the process of implementing joint professional activities. Terms form a professional component of information, are language units that form statements, and are included in both the receptive and productive vocabulary of specialists. Terminology is one of the necessary conditions for the implementation of intercultural communication in the professional sphere.

Medical terminology is a specific terminology used to achieve the purpose of communication in the health care field efficiently and precisely. Medical vocabulary may present a hurdle even to those who are very good in English, and also to those who cannot understand the borrowings from Greek and Latin languages. Medical terminology has a number of specific features, which differs it from other term systems. The majority of medical words are made of combining forms of Greek and Latin origin. This feature of word building can be used to help students deal with these words. Medical vocabulary is an open system with a large number of low-frequency words and newly created words. Teaching and learning all the words seem to be an impossible task. Hence, teaching students' vocabulary learning strategies for inferring the word meanings is more efficient than teaching every vocabulary item encountered. Besides, the abbreviations used in medical field are quite difficult and "the connections cannot be traced from the English".

As we all know very well, medical terminology is an important part in learning medical English. Terminology-centered study allows the students to overcome the obstacles and makes the study easier and more effective. Our investigation demonstrated overall positive assessment of the subject by the students. Thus, all this proves that the decision to teach medical terminology to the English medium students was correct. In conclusion, the opinion of the teachers throughout the world and findings of our survey demonstrate practicality of the course English Medical Terminology taught to English medium students. Students' opinion on the subject elicited during on-going needs analysis can show the ways of improving the teaching process.

Though students are relatively familiar with colloquial English phrases for describing medical conditions and anatomy, they are much less familiar with medical terminology. This thesis provides both a rational and suggested approach for teaching medical terminology. Acquiring proficiency in this specialized language is one of the fundamental challenges of medical studies.

Medical terminology is not commonly taught separately, but rather as incidental to clinical studies. Acquiring medical terminology will occur concurrently along with the vast body of clinical information that students must assimilate. Students develop some grasp of medical terminology through repeated encounter, inference and memorization, but this thesis considers these learning methods inherent in common practice both inefficient and insufficient [4].

From all of the above, we can make the following conclusions: 
-The terminology expresses special concepts firmly mastered by students, that is, those concepts that they freely operate and actively use when necessary.

-Terminologies are included in the active vocabulary of students, since they are necessary for the full implementation of professional activities, the formation and formulation of thoughts in a foreign language.

- The terminologies are used not in isolation, but in the professional context of foreign language speech, the degree of which is determined by the level of communicative competence.

-Teaching terminology in the framework of a communicative-oriented approach is directly related to the development of speech behavior that simulates real situations of professional activity.

Based on this research's findings, we can sum up, that teaching terminology in the process of verbal communication allows English teachers to provide a successful solution to the problem of forming a professionally-oriented communicative competence of non-philological students, which consists in developing their ability to carry out full-fledged professional communication in a foreign language.

\section{References}

1. Iwata, J., Clayton, J., \& Saravani, S. J. (2017). Learner autonomy, microcredentials and self-reflection: a review of a Moodle-based medical English review course. International Journal of Information and Communication Technology, 10(1), 42-50. https://doi.org/10.1504/IJICT.2017.081008

2. Siddall, R., \& Pitkänen, K. K. (2011). English by alternative means in the Faculty of Medicine. Out-of-classroom language learning, 23-38.

3. Hyland, K. (2009). Academic discourse: English in a global context. A\&C Black.

4. Weigle, S. C. (2002). Assessing writing. Ernst Klett Sprachen.

\section{Список литературь:}

1. Iwata J., Clayton J., Saravani S. J. Learner autonomy, microcredentials and self-reflection: a review of a Moodle-based medical English review course //International Journal of Information and Communication Technology. 2017. Vol. 10. №1. P. 42-50. https://doi.org/10.1504/IJICT.2017.081008

2. Siddall, R., \& Pitkänen, K. K. (2011). English by alternative means in the Faculty of Medicine. Out-of-classroom language learning, 23-38.

3. Hyland K. Academic discourse: English in a global context. A\&C Black, 2009.

4. Weigle S. C. Assessing writing. Ernst Klett Sprachen, 2002.

Работа поступила

в редакииюю 28.02.2020 г.
Принята к публикациии 05.03.2020 2.

Ссылка для циитирования:

Abidova M., Guzacheva N. Features of Medical Terminology Teaching in English Lessons // Бюллетень науки и практики. 2020. Т. 6. №4. С. 434-437. https://doi.org/10.33619/2414$2948 / 53 / 50$

Cite as (APA):

Abidova, M., \& Guzacheva, N. (2020). Features of Medical Terminology Teaching in English Lessons. Bulletin of Science and Practice, 6(4), 434-437. https://doi.org/10.33619/2414-2948/53/50 